\title{
Jurnal Ilmu Kehutanan
}

Journal of Forest Science

https://jurnal.ugm.ac.id/jikfkt

\section{Sifat Papan Partikel Bambu Petung (Dendrocalamus asper) dan Bambu Wulung (Gigantochloa atroviolacea) dengan Perlakuan Ekstraksi}

Properties of Particleboard made from Petung Bamboo (Dendrocalamus asper) and Wulung Bamboo (Gigantochloa atroviolacea) Particles with Extraction Treatment

\author{
Ragil Widyorini*, Ikhwan Syahri, \& Greitta Kusuma Dewi \\ Departemen Teknologi Hasil Hutan, Fakultas Kehutanan, Universitas Gadjah Mada, Yogyakarta, 55281 \\ Email : rwidyorini@ugm.ac.id
}

\section{HASIL PENELITIAN}

Riwayat Naskah :

Naskah masuk (received): 16 Juli 2019

Diterima (accepted): 15 Januari 2020

\section{KEYWORDS}

petung bamboo, wulung bamboo, cold-water extraction, hot-water extraction, citric acid

\section{KATA KUNCI}

bambu petung, bambu wulung, ekstraksi air dingin, ekstraksi air panas, asam sitrat

\begin{abstract}
Bamboo has extractives, which the percentage of extractive was different based on bamboo species. This research aimed to investigate the effect of extraction treatment at different bamboo species on the particleboard properties. Two types of bamboo were used, i.e. Petung bamboo (Dendrocalamus asper) and Wulung bamboo (Gigantochloa atroviolacea). Three extraction treatments were conducted to the bamboo particles before the particleboard manufacture, i.e. unextracted, cold-water extraction, and hot-water extraction. The particleboard was made in the size of $25 \mathrm{~cm} \times 25 \mathrm{~cm}$ $x 0.7 \mathrm{~cm}$, target density of $0.9 \mathrm{~g} / \mathrm{cm}^{3}$, citric acid content of $30 \%$, and pressing temperature of $180^{\circ} \mathrm{C}$ for $10 \mathrm{~min}$. The results showed that the interaction between extraction treatment and bamboo species significantly affected on the water absorption and internal bond strength, however bamboo species affected significantly on the moisture content, modulus of rupture, and modulus of elasticity. All of particleboards could met the requirement of the 13 type of Japanese Industrial Standard (JIS) A 5908. In this research, particleboards made from wulung bamboo particles without extraction treatment have properties that met the requirement of the 18 type and the products have potential to be as exterior materials for furniture. In general, an extraction treatment was not an important step on the manufacturing of bamboo particleboard using citric acid 30\% as adhesive. However, the extraction treatment could increase significantly the internal bond strength of particleboard made from petung bamboo.
\end{abstract}

\section{INTISARI}

Bambu memiliki kandungan ekstraktif dengan persentase yang berbeda antar jenis bambu. Penelitian ini bertujuan untuk mengetahui pengaruh perlakuan ekstraksi pada jenis bambu yang berbeda terhadap sifat papan partikel. Dua jenis bambu digunakan yaitu Bambu Petung (Dendrocalamus asper) dan Bambu Wulung (Gigantochloa atroviolacea). Perlakuan ekstraksi digunakan pada partikel bambu sebelum proses pembuatan papan partikel yaitu tanpa ekstraksi, ekstraksi air dingin dan ekstraksi air panas. Papan partikel dibuat dalam ukuran $25 \mathrm{~cm} \mathrm{x} 25 \mathrm{~cm}$ x 0,7 $\mathrm{cm}$, target kerapatan $0,9 \mathrm{~g} / \mathrm{cm}^{3}$, jumlah asam sitrat $30 \%$, serta kondisi pengempaan 
suhu $180^{\circ} \mathrm{C}$ selama 10 menit. Hasil penelitian menunjukkan bahwa interaksi perlakuan ekstraksi dan jenis bambu hanya berpengaruh signifikan pada sifat penyerapan air dan keteguhan rekat internal, sedangkan jenis bambu berpengaruh signifikan pada nilai kadar air, modulus patah dan modulus elastisitas. Semua papan partikel yang dihasilkan memenuhi standar Japanese Industrial Standard (JIS) A 5908 tipe 13. Pada penelitian ini, papan partikel dari bambu wulung tanpa perlakuan ekstraksi mempunyai nilai yang memenuhi standar tipe 18 dan berpotensi sebagai bahan baku untuk produk furnitur eksterior. Perlakuan ekstraksi dapat meningkatkan secara signifikan nilai keteguhan rekat internal papan partikel bambu petung, walaupun secara umum dengan jumlah asam sitrat 30\% perlakuan tersebut tidak diperlukan pada papan partikel bambu.

(C) Jurnal Ilmu Kehutanan -All rights reserved

\section{Pendahuluan}

Hutan merupakan eksosistem yang kompleks dengan komposisi yang beranekaragam mulai dari pohon, semak belukar, herba, dan rumput-rumputan yang terdiri atas ilalang, bambu dan lain-lain (FAO 2000; Arber 2010). Dalam upaya mempertahankan fungsi dan manfaat hutan, bambu berpotensi tinggi digunakan sebagai material pengganti kayu untuk kebutuhan konstruksi, mebel maupun kerajinan. Bambu memiliki kelebihan dibanding kayu yaitu tingkat pertumbuhan yang cepat dan siklus panen yang singkat (3-4 tahun) (Terefe et al. 2016; Arsad 2015). Bambu juga memiliki persebaran dan variasi jenis yang tinggi di dunia serta kekuatan yang menyamai bahkan melampaui kayu yaitu kekuatan tarik dan kekerasan (Liese 1987; Amada \& Untao 2001).

Bambu tersebar secara alami, buatan maupun invasif pada 52 negara dan pulau dari Amerika Selatan, Afrika, Asia, Australia hingga Selandia Baru dengan luas tutupan mencapai \pm 14 juta hektar di permukaan bumi (Canavan et al. 2017; Nirala et al. 2017). Tutupan tersebut $80 \%$ berada di Asia dan jenis terbanyak tumbuh di China (Nirala et al. 2017; Canavan et al. 2017; Liu et al. 2018). Bambu memiliki \pm 1.439 spesies/jenis di dunia yang setiap jenis tersebut memiliki karakteristik dan sifat tersendiri yang mempengaruhi penggunaan bambu tersebut (Bamboo Phylogeny Group 2012; Liese 1987; Sutardi et al. 2015; Liese \& Tang 2015). Di Indonesia, bambu tersebar di hampir semua provinsi dengan jumlah spesies lebih dari 150 dan total produksi sebesar 20,4 juta batang pada tahun 2018 (BPS 2018; Widjaja 1994). Bambu Wulung (Gigantochloa atroviolacea) dan Bambu petung (Dendrocalamus asper) merupakan 2 dari 10 jenis bambu yang banyak dibudidayakan di Sleman, Yogyakarta untuk penggunaan bahan konstruksi, mebel dan kerajinan (Data Inventarisasi Bambu Kab. Sleman 2015 dalam Parwita 2017).

Bambu memiliki kandungan pati yang tinggi pada saat berumur 3-4 tahun (Mohmod et al. 1992; Razak et al. 2007). Kandungan pati ini bervariasi tergantung oleh jenis bambu, musim, dan arah radial batang (Liese \& Tang 2015). Menurut Sutardi et al. (2015), kadar pati bambu petung, bambu apus, dan bambu wulung sebesar $15,8 \%, 9,42 \%$, dan $11,9 \%$. Di dalam bambu, pati terdapat pada sel parenkim (Liese \& Tang 2015). Keberadaan pati berpengaruh pada keawetan bambu dan mungkin dapat mengganggu proses perekatan bambu, sehingga perlu dihilangkan dengan cara ekstraksi. Selain pati, bambu juga memiliki ekstraktif lain seperti resin/getah, tanin, lilin dan garam anorganik yang kadarnya juga dipengaruhi oleh jenis bambu, kondisi pertumbuhan, umur dan bagian batang bambu (Liese et al. 1987).

Perlakuan ekstraksi yang umum dilakukan adalah dengan menggunakan air dingin dan air panas. Ekstraksi air dingin dapat melarutkan ekstraktif seperti tanin, getah, gula, dan zat warna, sedangkan ekstraksi air panas dapat melarutkan ekstraktif larut air dingin serta pati (ASTM D 1110-84 2002). Ekstraktif pada umumnya berpengaruh pada mekanisme perekatan dengan perekat baik sintetik maupun alami. Hasil penelitian Yemele et al. (2008) 
memperlihatkan sifat mekanik papan partikel black spruce yang terbuat dari partikel setelah mengalami perlakuan ekstraksi air panas mengalami penurunan dibandingkan papan partikel dari partikel tanpa perlakuan. Di sisi lain, perlakuan ekstraksi air panas diketahui tidak berpengaruh signifikan pada sifat rekat papan partikel pelepah salak dengan perekat asam sitrat sebanyak 20\% berat kering partikel (Widyorini et al. 2019). Jenis dan komposisi ekstraktif diduga turut mempengaruhi mekanisme perekatan yang terjadi. Kandungan pati pada bambu yang relatif tinggi diduga mempengaruhi sifat perekatan produk dari bambu. Pati pada umumnya memiliki sifat perekatan yang rendah dengan nilai penyerapan air yang tinggi (Wang et al. 2011; Damanhuri et al. 2018). Di sisi lain, menurut Widyorini et al. (2017), pati dalam jumlah tertentu pada perekat asam sitrat memiliki pengaruh positif pada peningkatan sifat perekatan papan partikel bambu petung. Oleh karena itu, pengaruh perlakuan ekstraksi bambu, yang juga dapat menghilangkan pati, terhadap sifat perekatannya dengan asam sitrat menarik untuk diketahui. Tujuan penelitian ini adalah untuk mengetahui pengaruh perlakuan ekstraksi air panas dan air dingin pada bambu petung serta bambu wulung terhadap sifat fisika dan mekanika papan partikel.

\section{Bahan dan Metode}

\section{Persiapan bahan}

Bahan baku yang digunakan adalah limbah pasahan bambu petung (Dendrocalamus asper) yang diperoleh dari pengrajin usuk dan reng di Cebongan, Sleman, Yogyakarta dan limbah iratan bambu wulung (Gigantochloa atroviolacea) yang diperoleh dari sentra kerajinan kipas di Kasongan, Bantul, Yogyakarta. Limbah tersebut kemudian digrinder menjadi partikel dan disaring menggunakan saringan ukuran 10 mesh untuk menyeragamkan ukuran partikel. Partikel yang lolos saringan 10 mesh kemudian dijadikan bahan baku papan partikel. Sebagai perekat/pengikat antar partikel, asam sitrat anhidrat (Weifang Ensign Industry Co. Ltd., China) digunakan tanpa adanya proses pemurnian lebih lanjut.
Sebagian partikel diberi perlakuan ekstraksi air dingin dan ekstraksi air panas berdasarkan standar ASTM D1110-84 (2002), sedangkan sebagian yang lain tidak diberi perlakuan. Ekstraksi air dingin dilakukan dengan merendam partikel pada air bersuhu ruangan $\left( \pm 27^{\circ} \mathrm{C}\right)$ selama $48 \mathrm{jam}$, sedangkan ekstraksi air panas dilakukan dengan merebus partikel pada air mendidih selama 3 jam. Setelah proses perendaman, partikel ditiriskan dan dikeringkan hingga kondisi kering udara (kadar air $\pm 12 \%$ ).

Perhitungan kadar ekstraktif kedua jenis bambu masing-masing perlakuan ekstraksi dihitung sebanyak 3 ulangan dengan menggunakan ukuran partikel yaitu lolos 40 mesh tertahan 6o mesh. Kerapatan tumpukan partikel hasil masing-masing perlakuan dihitung berdasarkan berat partikel tanpa proses penekanan per volume tertentu, dimana pada penelitian ini menggunakan kotak berukuran $10 \mathrm{~cm}$ $\mathrm{x} 10 \mathrm{~cm} \times 10 \mathrm{~cm}$.

\section{Pembuatan larutan perekat}

Larutan perekat dibuat dengan melarutkan asam sitrat di dalam pelarut air pada konsentrasi $59-60 \%$ seperti yang dilakukan oleh Widyorini et al. (2016). Perekat dibuat dalam kondisi larutan dengan tujuan mempermudah dan mengoptimalkan pelaburan perekat di permukaan partikel melalui metode penyemprotan. Sesuai dengan hasil penelitian Widyorini et al. (2016), jumlah asam sitrat yang digunakan pada penelitian ini adalah 30\% berdasarkan berat kering partikel (kadar air $\pm 12 \%$ ).

\section{Pembuatan papan partikel}

Pembuatan papan partikel dimulai dengan mencampurkan larutan perekat menggunakan alat semprot di permukaan partikel dan diaduk secara merata, kemudian partikel terlabur tersebut dikering-ovenkan hingga kadar air $\pm 4 \%$, dicetak pada forming box berukuran $25 \mathrm{~cm}$ x $25 \mathrm{~cm} \times 30$ $\mathrm{cm}$ dan dikempa panas pada suhu $180^{\circ} \mathrm{C}$, tekanan spesifik 3,5 MPa selama 10 menit. Target kerapatan dan target ketebalan papan partikel yang digunakan secara berturut-turut adalah $0,9 \mathrm{~g} / \mathrm{cm}^{3}$ dan $0,7 \mathrm{~cm}$. Setelah proses pengempaan panas, papan partikel dikondisikan pada ruangan dengan suhu $\pm 27^{\circ} \mathrm{C}$ dan 
kelembaban relatif $\pm 77 \%$ selama 1 minggu sebelum proses pengujian.

\section{Pengujian sifat papan partikel}

Pengujian sifat papan dilakukan berdasarkan Japanese Industrial Standard (JIS) A 5908 (2003). Pengujian sifat papan meliputi sifat fisika (kerapatan, kadar air, pengembangan tebal, penyerapan air dan kekasaran permukaan), serta sifat mekanika (keteguhan rekat internal, modulus patah dan modulus elastisitas). Kerapatan, kadar air, pengembangan tebal, penyerapan air, dan keteguhan rekat internal menggunakan sampel berukuran $5 \mathrm{~cm}$ x $5 \mathrm{~cm}$, sedangkan kekasaran permukaan, modulus patah dan modulus elastisitas menggunakan sampel berukuran $20 \mathrm{~cm} \times 5 \mathrm{~cm}$.

Pengembangan tebal dan penyerapan air diuji dengan mengukur tebal dan berat sampel setelah perendaman sampel pada air suhu ruangan $\left( \pm 27^{\circ} \mathrm{C}\right)$ selama 24 jam. Kekasaran permukaan papan dihitung berdasarkan nilai average surface roughness (Ra) pada 6 titik permukaan papan secara acak menggunakan alat SRG 4000 (Bosworth Instrument Cleveland, OH, USA). Keteguhan rekat internal diuji dengan cara mengaplikasikan beban tarik secara vertikal permukaan papan pada kecepatan $2 \mathrm{~mm} /$ menit hingga sampel rusak.

Modulus patah dan modulus elastisitas diuji dengan cara 3 point bending test pada kecepatan 10 $\mathrm{mm} / \mathrm{menit}$. Setiap pengujian dilakukan sebanyak 3 ulangan, dan selanjutnya dihitung nilai rata-rata dan standar deviasi. Pengujian pada kondisi basah dilakukan dengan merebus sampel selama 2 jam pada air mendidih dan dilanjutkan dengan merendam air pada suhu ruangan selama 1 jam (tipe B, JIS A 5908). Selanjutnya sampel diuji nilai modulus patah dan modulus elastisitas pada kondisi basah.

\section{Analisis data}

Analisis data untuk mengetahui signifikansi pengaruh faktor penelitian terhadap sifat papan (kadar air, pengembangan tebal, penyerapan air, keteguhan rekat internal, modulus patah dan modulus elastisitas pada kondisi kering) dilakukan dengan menggunakan analisis varian (Anova) dua arah pada taraf uji sebesar $1 \%$ dan $5 \%$. Pada sifat papan yang siginifikan dipengaruhi oleh faktor penelitian dilakukan uji lanjut menggunakan Tukey/ Honesty Significance Difference (HSD).

\section{Hasil dan Pembahasan}

\section{Sifat bambu petung dan bambu wulung}

Bambu petung dan bambu wulung memiliki komposisi kimia yang dapat dilihat pada Tabel 1. Perbedaan komposisi kimia bambu petung dan bambu wulung terlihat pada persentase holoselulosa (alfa selulosa dan hemiselulosa) dan persentase ekstraktif. Bambu petung yang digunakan pada penelitian ini memiliki persentase ekstraktif larut air panas yang hampir sama dengan ekstraktif larut air dingin. Kamthai \& Puthson (2005) menemukan ekstraktif larut air panas dan air dingin bambu petung 8,04\% dan 7,03\%. Berbeda dengan bambu petung, bambu wulung pada penelitian ini memiliki perbedaan persentase ekstraktif larut air panas dan air dingin sebanyak 0,99\%. Kisaran kandungan pati bambu wulung oleh Nafitri \& Lukmandaru (2013) sebesar 2,31 - 6,54\%, dan Sutardi et al. (2015) sebesar $11,9 \%$. Komponen gula dan pati dalam bambu termasuk dalam ekstraktif yang mudah larut dalam air. Perbedaan umur, bagian yang digunakan, serta musim pemanenan mungkin menyebabkan perbedaan kandungan pati pada bambu tersebut.

Tabel 1. Komposisi kimia partikel bambu petung dan bambu wulung

Table 1. Chemical compositions of petung bamboo and wulung bamboo particles

\begin{tabular}{lcc}
\hline \multirow{2}{*}{ Komposisi Kimia (\%) } & \multicolumn{2}{c}{ Jenis Bambu } \\
\cline { 2 - 3 } & $\begin{array}{l}\text { Bambu } \\
\text { Petung }\end{array}$ & $\begin{array}{c}\text { Bambu } \\
\text { Wulung }\end{array}$ \\
\hline Holoselulosa* & $72,99^{*}$ & $69,27^{*}$ \\
Alfa selulosa* & $43,41^{*}$ & $45,19^{*}$ \\
Hemiselulosa* & $29,58^{*}$ & $24,08^{*}$ \\
Lignin* & $24,00^{*}$ & $24,16^{*}$ \\
Ekstraktif larut air dingin & 9,06 & 10,46 \\
Ekstraktif larut air panas & 9,08 & 11,45 \\
\hline
\end{tabular}

Keterangan : *Widyorini et al. (2016), persentase berdasarkan sampel bebas ekstraktif

Remarks : : *Widyorini et al. (2016), percentage based on free extractives

\section{Sifat partikel dengan perlakuan ekstraksi}

Pengaruh perlakuan ekstraksi pada ukuran/ geometri partikel dapat dilihat melalui data kerapatan tumpukan (Tabel 2). Kerapatan tumpukan 
Tabel 2. Kerapatan tumpukan partikel bambu

Table 2. Bulk density of bamboo particle

\begin{tabular}{lcc}
\hline \multirow{2}{*}{ Sifat Papan } & \multicolumn{2}{c}{ Kerapatan tumpukan $\left(\mathrm{g} / \mathrm{cm}^{3}\right)$} \\
\cline { 2 - 3 } & Bambu Petung & Bambu Wulung \\
\hline Tanpa ekstraksi & 0,125 & 0,117 \\
Ekstraksi dingin & 0,128 & 0,121 \\
Ekstraksi panas & 0,129 & 0,121 \\
\hline
\end{tabular}

penting karena mempengaruhi nisbah pemampatan dan kekuatan papan partikel. Perlakuan ekstraksi membuat kerapatan tumpukan partikel sedikit meningkat. Hal ini terjadi diduga karena persentase partikel yang berukuran kecil meningkat dengan adanya perlakuan ekstraksi. Widyorini dan Puspitasari (2011) melaporkan bahwa partikel kayu setelah mengalami perlakuan ekstraksi air panas menjadi berukuran lebih halus dan berwarna lebih gelap dibandingkan tanpa perlakuan.

\section{Sifat papan partikel dengan perlakuan ekstraksi}

Semua papan partikel bambu petung dan bambu wulung yang dibuat dari partikel tanpa perlakuan ekstraksi maupun dengan perlakuan ekstraksi berhasil dibuat tanpa mengalami delaminasi. Sifat fisika papan partikel bambu petung dan bambu wulung dapat dilihat pada Tabel 3. Kadar air papan tidak dipengaruhi oleh perlakuan ekstraksi secara signifikan, namun kadar air papan berbeda signifikan antar 2 jenis bambu (Tabel 4). Kadar air papan partikel dari bambu petung berkisar 7,41-7,76\%, sedangkan kadar air papan partikel dari bambu wulung berkisar 6,57-6,91\% (Tabel 3). Semua papan partikel memiliki nilai kadar air yang memenuhi persyaratan JIS A 5908 (2003), yaitu 5-13\%.

Kekasaran permukaan papan partikel bambu petung dan bambu wulung berada pada kisaran 5,82-6,78 $\mu \mathrm{m}$ (Tabel 3). Nilai kekasaran permukaan tersebut masih di atas (lebih kasar) nilai kekasaran permukaan papan komersial di Jepang yaitu 3,67-

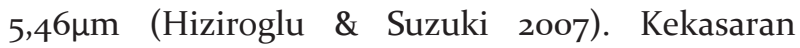
permukaan merupakan sifat yang penting karena papan partikel biasanya dilapis dengan bahanbahan seperti venir, kertas, maupun coating dalam pengaplikasiannya untuk mebel, panel, dan lainlain. Pada umumnya, permukaan papan partikel yang halus dapat mempermudah dalam proses pelapisan. Di sisi lain, permukaan yang cukup kasar diperlukan karena memiliki luas permukaan yang lebih tinggi sehingga ketahanan pelapisan dengan resin (coating) menjadi lebih kuat (Rolleri \& Roffael 2010). Dampak negatif jika permukaan papan partikel terlalu kasar adalah membutuhkan bahan pelapis yang lebih banyak untuk mendapatkan penampakan yang halus.

Tabel 3. Sifat fisika papan partikel bambu petung dan bambu wulung

Table 3. Physical properties of particleboards made from petung bamboo and wulung bamboo

\begin{tabular}{|c|c|c|c|c|c|}
\hline \multirow[b]{2}{*}{ Jenis Bambu } & \multirow[b]{2}{*}{ Perlakuan Ekstraksi } & \multicolumn{4}{|c|}{ Sifat Fisika Papan Partikel } \\
\hline & & Kadar air (\%) & $\begin{array}{c}\text { Kekasaran Permu- } \\
\text { kaan }(\mu \mathrm{m})\end{array}$ & $\begin{array}{c}\text { Pengembangan } \\
\text { tebal }(\%)\end{array}$ & Penyerapan air (\%) \\
\hline \multirow{3}{*}{ Bambu Petung } & Tanpa ekstraksi & $7,76(1,16)$ & $6,14(0,94)$ & $5, \mathrm{oo}(1,18)$ & $27,03(0,78)$ \\
\hline & Ekstraksi air dingin & $7,47(0,35)$ & $5,82(o, 69)$ & $5,81(1,04)$ & $18,87(2,13)$ \\
\hline & Ekstraksi air panas & $7,41(0,67)$ & $6,36(1,29)$ & $5,24(0,68)$ & $21,39(0,91)$ \\
\hline \multirow{3}{*}{$\begin{array}{l}\text { Bambu } \\
\text { Wulung }\end{array}$} & Tanpa ekstraksi & $6,57(0,73)$ & $6,78(0,60)$ & $4,55(0,60)$ & $25,85(1,31)$ \\
\hline & Ekstraksi air dingin & $6,91(0,38)$ & $6,17(0,40)$ & $6,51(0,65)$ & $21,90(0,41)$ \\
\hline & Ekstraksi air panas & $6,81(0,64)$ & $6,58(1,34)$ & $5,87(1,08)$ & $23,08(0,58)$ \\
\hline
\end{tabular}

Keterangan : angka dalam () menunjukkan standar deviasi

Remark : () indicates standard deviation 
Tabel 4. Analisis varian

Table 4. Analysis of variance

\begin{tabular}{llll}
\hline \multirow{2}{*}{ Sifat Papan } & \multicolumn{2}{c}{ Signifikansi } \\
\cline { 2 - 4 } & Faktor Jenis Bambu & Faktor Ekstraksi & $\begin{array}{l}\text { Interaksi Faktor jenis bambu \& faktor } \\
\text { perlakuan ekstraksi }\end{array}$ \\
\hline Kadar air & $3,60 \times 10-2^{*}$ & $9,81 \times 10-1 \mathrm{~ns}$ & $6,94 \times 10-1 \mathrm{~ns}$ \\
Pengembangan tebal & $4,98 \times 10-1 \mathrm{~ns}$ & $6,09 \times 10-2 \mathrm{~ns}$ & $4,84 \times 10-1 \mathrm{~ns}$ \\
Penyerapan air & $5,4 \times 10-2 \mathrm{~ns}$ & $3,66 \times 10-6 * *$ & $2,54 \times 10-2 *$ \\
Keteguhan rekat internal & $7,63 \times 10-8 * *$ & $1,05 \times 10-1 \mathrm{~ns}$ & $1,52 \times 10-5 * *$ \\
Modulus patah kondisi kering & $3,41 \times 10-3^{* *}$ & $3,62 \times 10-1 \mathrm{~ns}$ & $2,40 \times 10-1 \mathrm{~ns}$ \\
Modulus elastisitas kondisi kering & $3,01 \times 10-3^{* *}$ & $4,88 \times 10-1 \mathrm{~ns}$ & $9,14 \times 10-2 \mathrm{~ns}$ \\
\hline
\end{tabular}

Keterangan : ns : tidak signifikan, * : signifikan pada taraf uji $5 \%$, ${ }^{* *}$ : signifikan pada taraf uji $1 \%$

Remarks : ns : non-significant, ${ }^{*}$ : significant at $5 \%$ test level, ${ }^{* *}$ : significant at $1 \%$ test level

Pengembangan tebal papan partikel cenderung mengalami peningkatan dengan adanya perlakuan ekstraksi pada bahan baku (Tabel 3), walaupun tidak secara signifikan (Tabel 4). Pada penelitian ini menunjukkan bahwa semua papan partikel mempunyai nilai pengembangan tebal dibawah 7\%, yang memenuhi persyaratan JIS A 5908 untuk papan partikel (maksimal 12\%). Tren peningkatan nilai pengembangan tebal akibat perlakuan ekstraksi terjadi pada penelitian Lamaming et al. (2013) dan Widyorini et al. (2019). Namun, Widyorini et al. (2019) lebih lanjut menunjukkan bahwa persentase peningkatan pengembangan tebal tersebut menurun dengan semakin meningkatnya jumlah perekat asam sitrat. Hal ini diduga karena jumlah perekat yang digunakan cukup tinggi yaitu $20 \%$. Halligan et al. (1970) menyebutkan bahwa pengembangan tebal dipengaruhi oleh jumlah perekat dan juga faktor lain sepertijenis kayu, geometri partikel, kerapatan papan, efisiensi pencampuran, dan kondisi pengempaan (springback). Selanjutnya berbeda dengan Lamaming et al. (2013) dan Widyorini et al. (2019), nilai penyerapan air pada penelitian ini menurun ketika bahan baku diekstraksi. Nilai penyerapan air dipengaruhi secara signifikan oleh perlakuan ekstraksi dan interaksi antara perlakuan ekstraksi dan jenis bambu yang digunakan (Tabel 4). Hal ini diduga disebabkan oleh pengaruh penghilangan zatzat ekstraktif yang bersifat hidrofilik pada bambu yang menyebabkan sifat penyerapan air papan partikel menjadi menurun.

Nilai keteguhan rekat internal papan partikel pada penelitian ini sangat tinggi berkisar dari o,88-1,94 MPa, diatas tipe 18 JIS A 5908 (2003) yaitu minimal o,3 MPa. Hal tersebut menunjukkan bahwa papan partikel bambu berperekat asam sitrat sangat berpotensi digunakan sebagai bahan baku furnitur. Nilai keteguhan rekat internal papan partikel penelitian ini sebagian besar melebihi nilai keteguhan rekat internal pada papan partikel sweet sorghum bagasse dengan jenis dan jumlah perekat yang sama yaitu sebesar $\pm 1 \mathrm{MPa}$ (Kusumah et al. 2016). Papan partikel dari bambu petung dengan perlakuan ekstraksi hasil penelitian ini mempunyai nilai keteguhan rekat internal 1,48 - 1,52 MPa, sedangkan papan partikel bambu petung dengan menggunakan perekat asam sitrat-pati $(87,5 / 12,5$, $\mathrm{g} / \mathrm{g} \%$ ) hanya sebesar 1,21 MPa (Widyorini et al. 2017).

Nilai keteguhan rekat internal berbeda signifikan karena pengaruh jenis bambu dan interaksi antara faktor jenis bambu dan perlakuan ekstraksi (Tabel 4). Papan partikel dari bambu wulung memiliki keteguhan rekat internal lebih tinggi (1,94 MPa) dibanding dengan bambu petung (o,88 MPa). Hal ini diduga juga dipengaruhi oleh kerapatan tumpukan bambu wulung $\left(0,117-0,121 \mathrm{~g} / \mathrm{cm}^{3}\right)$ yang lebih rendah dibanding dengan kerapatan tumpukan bambu petung $\left(0,125-0,129 \mathrm{~g} / \mathrm{cm}^{3}\right)$. Kerapatan tumpukan yang rendah menyebabkan nisbah pemampatan (compaction ratio) tinggi sehingga kontak antar partikel menjadi lebih baik serta sifat lentur (bending) dan kekakuan menjadi tinggi (Nazerian et al. 2011). Kontak antar partikel yang baik menyebabkan kekuatan rekat antar partikel menjadi tinggi.

Pengaruh interaksi perlakuan ekstraksi dan jenis bambu berperan nyata pada nilai keteguhan rekat internal. Hal ini terlihat dari tren yang berbeda antar 2 jenis bambu. Perlakuan ekstraksi membuat keteguhan rekat internal papan partikel bambu petung meningkat hingga $73 \%$, namun justru membuat keteguhan rekat internal papan 
bambu wulung cenderung menurun walaupun tidak signifikan. Gambar 1 menunjukkan keteguhan rekat internal papan partikel bambu petung setelah perlakuan ekstraksi air panas dan dingin secara berurutan adalah sebesar 1,48 \pm 0,11 MPa dan 1,52 \pm o,12 MPa. Disisi lain, keteguhan rekat internal papan partikel bambu wulung setelah perlakuan ekstraksi air panas sebesar 1,69 \pm 0,02 MPa dan ekstraksi air

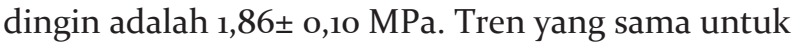
bambu wulung juga ditemukan oleh Widyorini et al. (2019) pada penghilangan ekstraktif air panas dari partikel pelepah salak. Gugus hidroksil $(\mathrm{OH})$ pada komponen ekstraktif diduga turut berperan pada pembentukan ikatan ester dengan asam sitrat. Perbedaan tren pada kedua jenis bambu pada penelitian ini diduga disebabkan oleh perbedaan komponen dan komposisi ekstraktif maupun karakteristik partikel setelah perlakuan ekstraksi. Penelitian lebih lanjut mengenai komponen serta komposisi ekstraktif air dingin dan air panas kedua jenis bambu menarik untuk dilakukan agar bisa menjelaskan lebih detil mekanisme perekatan dengan asam sitrat. Perubahan karakteristik partikel akibat perlakuan ekstraksi seperti distribusi ukuran partikel menarik untuk diteliti lebih lanjut karena berkaitan dengan perubahan luas bidang kontak permukaan perekatan dan kekuatan rekat yang dihasilkan.

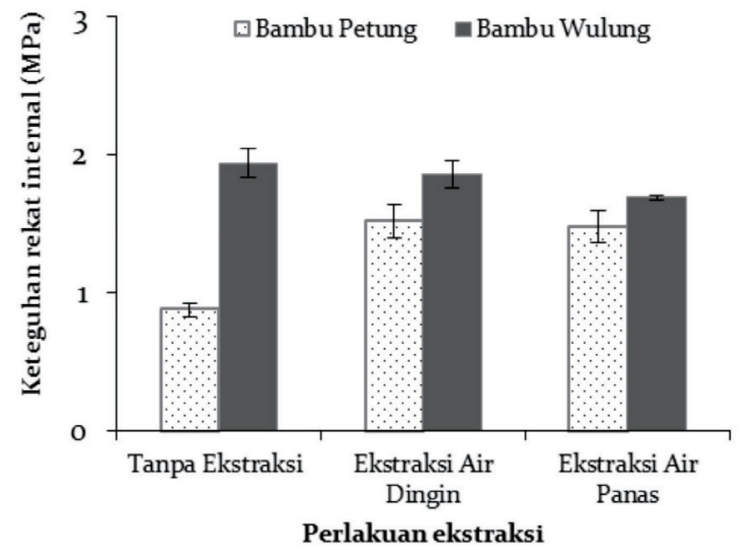

Gambar 1. Keteguhan rekat internal papan partikel bambu petung dan bambu wulung. Garis vertikal yang melewati bar menunjukkan standar deviasi

Figure 1. Internal bonding strength of particleboards made from petung bamboo and wulung bamboo. Vertical lines through the bars represent the standard deviation
Sifat modulus patah dan modulus elastisitas papan partikel pada kondisi kering dapat dilihat pada Gambar 2. Sama seperti sifat keteguhan rekat internal, papan partikel dari bambu wulung mempunyai nilai modulus patah dan modulus elastisitas yang lebih tinggi dibanding bambu petung pada masing-masing perlakuan ekstraksi. Tabel 4 menunjukkan bahwa nilai modulus patah dan elastisitas hanya dipengaruhi oleh jenis bambu. Nilai modulus patah papan partikel bambu wulung dapat memenuhi standar tipe 18 (min. 18 $\mathrm{MPa}$ ), sedangkan modulus patah papan partikel bambu petung memenuhi standar tipe 13 (min. 13 MPa). Disisi lain, nilai modulus elastisitas papan partikel bambu wulung juga diketahui lebih tinggi 56\% dibandingkan modulus elastisitas papan partikel bambu petung. Perlakuan ekstraksi tidak memberikan pengaruh yang nyata pada modulus patah dan modulus elastisitas papan berdasarkan hasil analisis varian (Tabel 4), namun terdapat tren yang sedikit meningkat pada bambu petung terekstrak dan sedikit menurun pada bambu wulung terekstrak, sama seperti keteguhan rekat internal (Gambar 1).

Gambar 3 menunjukkan nilai modulus patah dan modulus elastisitas papan partikel bambu pada kondisi basah setelah direbus selama 2 jam dan direndam air pada suhu ruangan selama 1 jam (pengujian tipe B, JIS A 5908). Nilai modulus patah dalam kondisi basah masih tinggi, yaitu berkisar antara 5,03 - 9,25 $\mathrm{MPa}$ atau retensi sebesar 35 49\% dari nilai modulus patah dalam kondisi kering. Berdasarkan standar JIS A 5908, papan partikel dari bambu wulung tanpa ekstraksi memenuhi standar tipe 18 (minimal $9 \mathrm{MPa}$ ), sedangkan papan partikel dengan perlakuan ekstraksi memenuhi standar tipe 13 (minimal 6,5 MPa). Semua papan partikel dari bambu petung tidak ada yang memiliki nilai modulus patah dalam kondisi basah diatas 6,5 MPa. Di sisi lain, nilai modulus elastisitas dalam kondisi basah berkisar antara 1,66 - 2,66 GPa atau retensi sebesar 43 - 52\% dari nilai modulus elastisitas dalam kondisi kering. Hasil pengujian basah tipe B ini menunjukkan bahwa papan partikel dari bambu, khususnya bambu wulung, dengan perekat asam sitrat mempunyai potensi untuk digunakan sebagai bahan baku untuk produk eksterior. 


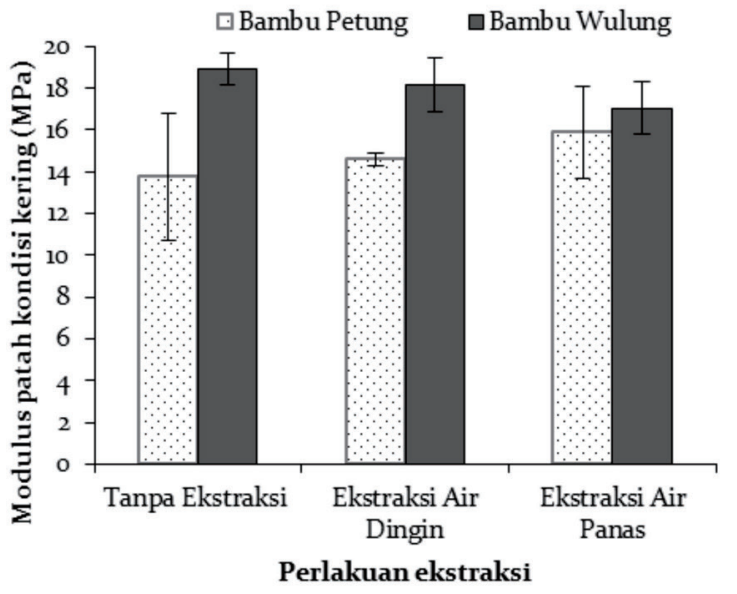

(a)

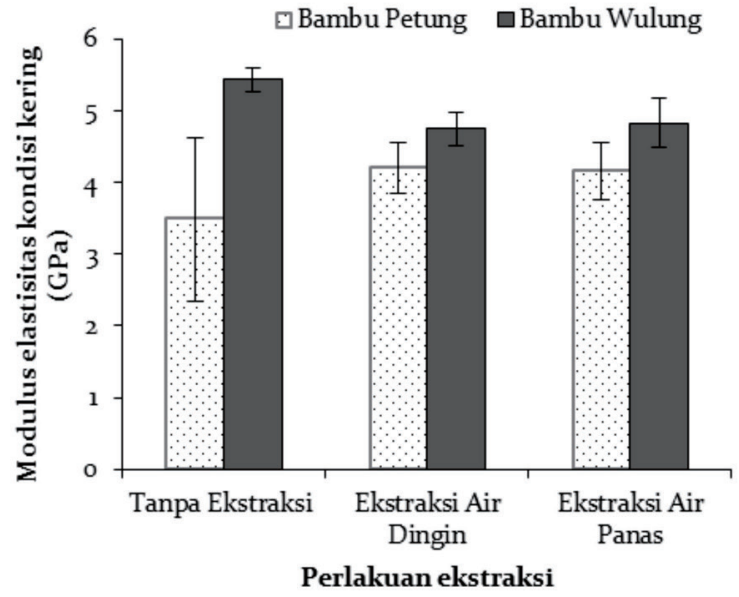

(b)

Gambar 2. Modulus patah (a) dan modulus elastisitas (b) pada kondisi kering papan partikel bambu petung dan bambu wulung. Garis vertikal yang melewati bar menunjukkan standar deviasi

Figure 2. Modulus of rupture (a) and modulus of elasticity (b) in dry condition of particleboards made from petung bamboo and wulung bamboo. Vertical lines through the bars represent the standard deviation

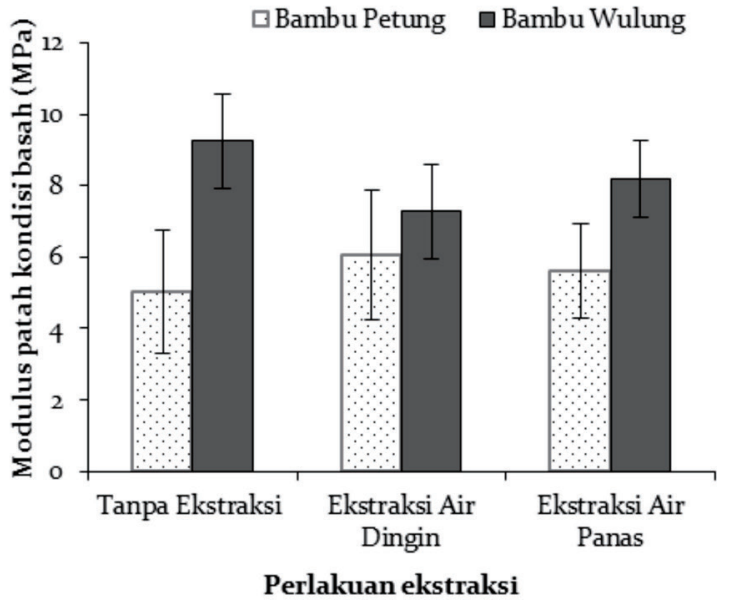

(a)

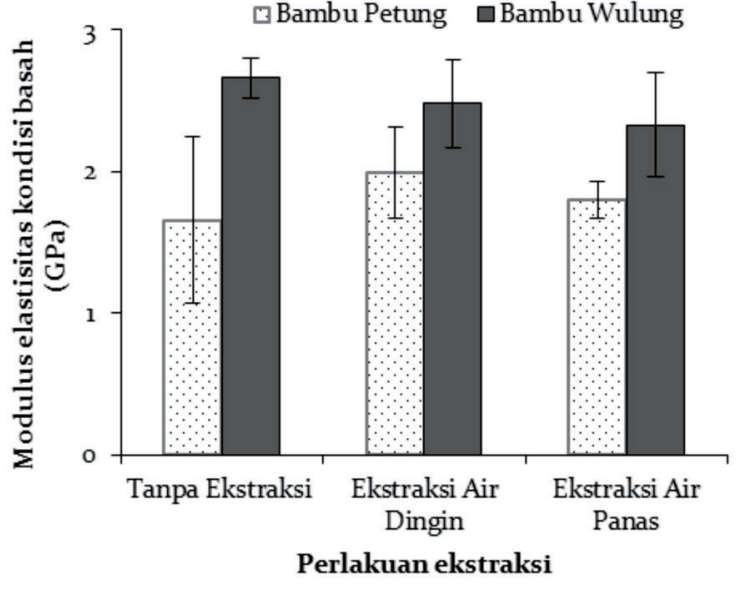

(b)

Gambar 3. Modulus patah (a) dan modulus elastisitas (b) pada kondisi basah papan partikel bambu petung dan bambu wulung. Garis vertikal yang melewati bar menunjukkan standar deviasi

Figure 3. Modulus of rupture (a) and modulus of elasticity (b) in wet condition of particleboards made from petung bamboo and wulung bamboo. Vertical lines through the bars represent the standard deviation

\section{Kesimpulan}

Pada penelitian ini, interaksi perlakuan ekstraksi dan jenis bambu berpengaruh signifikan pada sifat penyerapan air dan keteguhan rekat internal. Jenis bambu berpengaruh signifikan pada nilai kadar air, modulus patah dan modulus elastisitas. Berdasarkan nilai fisika dan mekanika diatas, terlihat bahwa papan partikel kedua jenis bambu dengan perekat asam sitrat sangat potensial sebagai bahan baku furnitur karena memiliki nilai diatas standar yang dipersyaratkan JIS A 5908, dengan nilai keteguhan rekat internal diatas o,8 $\mathrm{MPa}$, nilai modulus patah diatas 13 MPa dan nilai modulus elastisitas diatas 3 GPa. Nilai tertinggi papan partikel diperoleh dari papan yang dibuat dari partikel bambu wulung tanpa perlakuan ekstraksi dengan sifat memenuhi tipe 18 (JIS A 5908 2003). Disisi lain, secara umum dapat disimpulkan bahwa perlakuan ekstraksi dengan jumlah perekat asam sitrat 30\% tidak diperlukan pada papan partikel bambu. Akan tetapi, perlakuan ekstraksi bisa meningkatkan secara signifikan nilai keteguhan rekat internal papan partikel bambu petung. 


\section{Ucapan Terima Kasih}

Penulis mengucapkan terimakasih atas bantuan dana penelitian dari Kementrian Riset, Teknologi dan Perguruan Tinggi, Republik Indonesia dan Universitas Gadjah Mada melalui Hibah Penelitian Terapan Unggulan Perguruan Tinggi no. 842/UN1. PIII/LT/DIT-LIT/2016 dan no. 2344/UN1.PIII/LT/ DIT-LIT/2017.

\section{Daftar Pustaka}

Amada S, Untao, S. 2001. Fracture properties of bamboo. Composites: Part B 32(5):451-459.

Arber, A. 2010. The Gramineae: A Study of Cereal, Bamboo and Grass. Cambridge University Press, Inggris.

Arsad, E. 2015. Teknologi pengolahan dan manfaat bambu. Jurnal Riset Industri Hasil Hutan 7(1):45-52.

ASTM. 2002. ASTM D-1110-84. Standard test method for water solubility of wood. Annual Books of ASTM Standard. Baltimore.

Bamboo Phylogeny Group. 2012. An updated tribal and subtribal classification of the bamboos (Poaceae: Bambusoideae). The Journal of The American Bamboo Society 24(1): 1- 10.

BPS. 2018. Statistik Produksi Kehutanan 2018. Badan Pusat Statistik, Jakarta.

Canavan S, Richardson DM, Visser V, Le Roux JJ, Vorontsova MS, Wilson JRU. 2017. The global distribution of bamboos: Assessing correlates of introduction and invasion. AoB Plants 9(1):plwo78 1-18.

Damanhuri AAM, Lubis AMHS, Hariri A, Hussin MSF. 2018. Effect of corn starch and wood glue to physical and mechanical properties of rice-husk based particleboard. Hlm 210-211 dalam Abdollah MFB, editor. Proceedings of Mechanical Engineering Research Day, 1-2 Mei 2018. Centre for Advanced Research on Energy, Faculty of Mechanical Engineering, Universiti Teknikal Malaysia Melaka, Malaysia.

FAO. 20oo. Land cover classification system (LCCS): Classification concepts and user manual. Publishing and Multimedia Service, Information Division, FAO, Italia.

Halligan AF. 1970. A review of thickness swelling in particleboard. Wood Science and Technology 4:301312.

Hiziroglu S, Suzuki S, 2007. Evaluation of surface roughness of commercially manufactured particleboard and medium density fiberboard in Japan. Journal of Materials Processing Technology 184(1-3):436-440.

JIS A 5908. 2003. Particleboards. Japanese Standard Association, Tokyo.

Kamthai S, Puthson P. 2005. The physical properties, fiber morphology and chemical compositions of sweet bamboo (Dendrocalamus asper Becker). Kasetsart Journal-Natural Science 39(4):581-587.

Kusumah SS, Umemura K, Yoshioka K, Miyafuji H, Kanayama K. 2016. Utilization of sweet sorghum bagasse and citric acid for manufacturing of particleboard I: Effects of pre-drying treatment and citric acid content on the board properties. Industrial Crops and Products 84:34-42.

Lamaming J, Sulaiman O, Sugimoto T, Hashim R, Said N, Sato M. 2013. Influence of chemical components of oil palm on properties of binderless particleboard. BioResources 8(3):3358-3371.

Liese W. 1987. Anatomy and properties of bamboo. Hlm. 196-208 dalam Rao AN, Dhanarajan G, Sastry CB, editor. Proceedings of the International Bamboo Workshop, 6-14 Oktober 1985. The Chinese Academy of Forestry of China and International Development Research Center of Canada, Hangzhou.

Liese W, Tang TKH. 2015. Properties of bamboo culm. Hlm. 227-256 dalam Liese W, Kohl M, editor. Bamboo-The Plant and its Uses. Springer, Swiss.

Liu W, Hui C, Wang F, Wang M, Liu G. 2018. Review of the resources and utilization of bamboo in China. Hlm. 133-142 dalam Khalil HPSA, editor. Bamboo: Current and Future Prospects. IntechOpen, London.

Mohmod AL, Khoo KC, Nor AMA. 1992. Carbohydrates in some natural stand bamboos. Journal of Tropical Forest Science 4(4): 310-316.

Nafitri M, Lukmandaru G. 2013. Sifat kimia bambu hitam (Gigantochloa sp) pada perbedaan arah rasial dan ketinggian tempat tumbuh. Hlm. 318-324 dalam Suwinarti W, Kusuma IW, Erwin, Ismail, editor. Prosiding Masyarakat Peneliti Kayu Indonesia (Mapeki) XVI, 6 November 2013. Mapeki, Balikpapan.

Nazerian M, Ghalehno MD, Shojaiishad M, Sharifpoor H, Taftiyan MH. 2011. Properties of three-layer particleboard made from wood of athel (Tamarix aphylla) and pruning particles of almond (Amygdalus communis) dan pistachio (Pistacia vera). Jurnal of Basic and Applied Scientific Research 1(8):837-843.

Nirala DP, Ambasta N, Kumari P. 2017. A review on distribution of bamboos. Life Sciences Leaflets 92:7078 .

Parwita IWPA. 2017. Landasan konseptual perencanaan dan perancangan bamboo community centre sebagai saranan budidaya bambu di Kabupaten Sleman, D.I. Yogyakarta. Tesis (Tidak dipublikasikan). Magister Teknik Arsitektur, Universitas Atma Jaya, Yogyakarta.

Razak W, Janshah M, Hashim WS, Shirley B. 2007. Morphological and anatomical characteristics of managed natural bamboo stands-Gigantochloa scortechinii. Journal of Bamboo and Ratan 6(1-2):115121.

Rolleri A, Roffael E. 2010. Influence of the surface roughness of particleboards and their performance toward coating. Manderas Ciencia y Technologia 12(2):143148 . 
Sutardi SR, Nadjib N, Muslich M, Jasni, Sulastiningsih IM, Komaryati S, Suprapti S, Abdurrahman, Basri E. 2015. Informasi Sifat Dasar dan Kemungkinan Penggunaan 10 Jenis Bambu. Pusat Penelitian dan Pengembangan Hasil Hutan, Kementerian Lingkungan Hidup dan Kehutanan, Bogor.

Terefe R, TeshomeSD, Sanbato M, Daba M. 2016. Adaptation and growth performance of different lowland bamboo species in Bako, West Shoa, Ethiopia. Journal of Natural Sciences Research 6(9):61-65.

Wang Z, Gu Z, Hong Y, Cheng L, Li Z. 2011. Bonding strength and water resistance of starch-based wood adhesive. Carbohydrate Polimers 88:699-706.

Widjaja EA. 1994. Strategi Penelitian Bambu Indonesia. Yayasan Bambu Lingkungan Lestari, Bogor.

Widyorini R, Puspitasari FE. 2011. Pengaruh perlakuan ekstraksi dan waktu kempa terhadap sifat papan partikel tanpa perekat dari limbah serbuk gergajian kayu mahoni. Hlm. 225 -232 dalam Sulistyo J, Widyorini R, Lukmandaru G, Rofii MN, Prasetyo VE, editor. Prosiding Masyarakat Peneliti Kayu Indonesia (Mapeki) XIV, 2 November 2011. Mapeki, Balikpapan.

Widyorini R, Umemura K, Isnan R, Putra DR, Awaludin A, Prayitno TA. 2016. Manufacture and properties of citric acid bonded particleboard made from bamboo materials. European Journal of Wood and Wood Products 74:57-65.

Widyorini R, Umemura K, Kusumaningtyas AR, Prayitno TA. 2017. Effect of starch addition on properties of citric acid-bonded particleboard made from bamboo. BioResources 12(4):8068-8077.

Widyorini R, Umemura K, Soraya DK, Dewi GK, Nugroho WD. 2019. Effect of citric acid and extractives treatment on the manufacturing process and properties of citric acid-bonded Salacca frond particleboard. BioResources 14(2):4171-4180.

Yemele MCN, Koubaa A, Diouf PN, Blanchet P, Cloutier A, Stevanovic T. 2008. Effect of hot water treatment of black spruce and trembling aspen bark raw material on the physical and mechanical properties of bark particleboards. Wood and Fiber Science 4o(3):339-351. 